\title{
Cataract and Pterygium Surgery Results in Venezuelan Patients Treated in the Misión Milagro Program
}

\author{
Idalia Triana MD MPH, Oaris de los Ángeles Socarrás MD, Nelsis Rondón MD
}

\begin{abstract}
An intervention to address vision loss was carried out in 2008 in Táchira, Venezuela, by health teams of the joint CubanVenezuelan initiative known as Misión Milagro. It included active case identification of patients with ophthalmologic conditions and, where warranted, surgery, followup, rehabilitation and medical discharge. From a universe of 345 patients aged $\geq 18$ years with ophthalmologic conditions found, 210 were selected for cataract or pterygium surgery. Of cataract patients, $55.2 \%$ recovered optimal vision within three months after surgery, as did $90.9 \%$ of those with pterygium; frequency of complications was $15.4 \%$ in cataract patients and $41.7 \%$ in pterygium patients. The intervention was considered successful, although many patients' low-income status required premature postoperative return to their jobs and other labors, a factor considered detrimental to optimal recovery.
\end{abstract}

KEYWORDS Health disparities, medical missions, medical assistance, ophthalmology, cataract/extraction, pterygium/surgery, surgery, Venezuela, Cuba

\section{INTRODUCTION}

There are approximately 39 million blind persons in the world and a further 246 million with low vision (severe or moderate visual impairment); about $90 \%$ of them live in developing countries where the probability of going blind is ten times that in industrialized countries.[1]

There is a well-established relationship between poverty and blindness.[2] Prevalence among countries varies inversely with levels of social and economic development: up to $1 \%$ in lower-income countries with deficient health services compared to $0.25 \%$ in more developed countries. The main causes of blindness in developing countries are cataracts, glaucoma, diabetic retinopathy and infectious diseases, such as trachoma and onchocerciasis. The frequency of other eye conditions such as pterygium, palpebral ptosis and strabismus, is high in both children and adults.[3] Some five million people in Latin America require various types of ophthalmologic surgeries, while in the Caribbean, the figure is approximately half a million.[1,2]

Globally, cataracts are the number one cause of preventable blindness, with an estimated 20 million people blinded by the condition.[1] To even gradually eliminate cataracts as a health problem, some $2000-4000$ surgeries per million population ( $\mathrm{pmp}$ ) would be needed annually. These are rates seen only in highly developed countries and have been unattainable in developing countries, due to limited access to medical services and high surgical costs. [3] This inequity is illustrated in the cataract surgical rate (CSR), defined as the number of operations performed annually pmp, an indicator of eye care coverage.[4,5] CSR varies significantly from country to country (and even within countries), for example, from approximately $5000 \mathrm{pmp}$ in the United States to 200 in all of Africa.[4] Thanks to international initiatives and programs such as
VISION 2020, it is anticipated that CSR will markedly increase, especially in developing countries.[6] CSR rates for Venezuela were not available at the time of our intervention.

In Venezuela, Misión Milagro is an initiative built on information gleaned from a bilateral cooperation program between Cuba and Venezuela-Barrio Adentro-which posts Cuban-Venezuelan medical teams at the primary care level throughout Venezuela to provide free medical services.[7] Misión Milagro offers free ophthalmological care to people of limited means, aimed at improving or restoring sight of those affected by cataracts, pterygium and other conditions causing vision loss.[8,9]

On July 10, 2004, the first 50 Venezuelan patients enrolled in the program received surgeries in Cuba, where Cuban patients were also enrolled.[10] However, the long-term goal was to preserve, improve or restore the sight of six million low-income Latin American and Caribbean people during the following decade. Using state-of-the-art ophthalmologic technology, Cuban surgeons and technicians created capacity to perform surgeries on approximately one million patients annually. Later, expanded capacities and multilateral agreements permitted extension to some 30 countries in Latin America and the Caribbean, Africa, and Asia.[11] Programs such as this, of which Misión Milagro is the largest,[12] offer the only option available to disadvantaged people, since the cost of such surgeries ranges from US $\$ 400$ to US $\$ 600$ in these regions. $[13,14]$

This article describes Misión Milagro's work, methodology and results in the Venezuelan town of San Cristóbal de Táchira in Táchira state, also recording previously unreported baseline data for ophthalmological conditions in the area.

\section{INTERVENTION}

Objective The Misión Milagro program was implemented at the Simón Bolivar Comprehensive Diagnostic Center (a multispecialty community health center) in San Cristóbal de Táchira, a city of approximately 500,000 in Táchira state, Venezuela, during the second half of 2008. The objective was to surgically improve visual acuity (VA) of low-income persons with cataracts and pterygium who otherwise would not have been able to afford such care.

Description The intervention covered active case-finding, surgery, and postoperative followup through vision rehabilitation and medical discharge. In a grassroots effort with proactive community participation, door-to-door canvassing to identify potential cases was conducted on weekends in cooperation with beneficiary community volunteers-in particular from the Frente Francisco Miranda (a local volunteer organization) and from community councils (social workers and health promoters)who were recruited and trained by Misión Milagro staff. Primary selection of patients was accomplished through an initial eye exam at the Center (visual acuity, anterior segment biomicroscopy, and when possible, direct ophthalmoscopy). A total of 345 patients aged $\geq 18$ years were found to have eye conditions; of 
these, 210 , the study population, had operable cataracts (78) or pterygium (132). The intervention and outcomes study were approved by the scientific board of the Cuban Misión Médica Coordinating Office in Táchira state, in collaboration with local Venezuelan authorities, and patients provided written informed consent.

Based on primary information from individual clinical histories and a questionnaire designed to yield information on household income and patient satisfaction, a database was created documenting percentages of the following variables in the study population: age (age groups: 18-39, 40-59 and $\geq 60$ years), sex, education (illiterate, primary school, high school or university), occupation (employed, retired, unemployed, student or housewife), financial situation, how patients learned about Misión Milagro, complications, postoperative vision recovery three months post-surgery (VA: optimal 0.8-1.0; good 0.6-0.7; fair $\leq 0.5$ ) and patient satisfaction. Financial situation was classified by Venezuelan living standards at the time by level of declared average annual income of household members: level one $>600,000$ bolivars, level two 400,000-600,000 bolivars, and level three $<400,000$ bolivars.
Table 1: Complications of cataract and pterygium surgery, Táchira, Venezuela, 2008

\begin{tabular}{|c|c|c|c|c|c|c|}
\hline & \multicolumn{3}{|c|}{ Cataract } & \multicolumn{3}{|c|}{ Pterygium } \\
\hline Complication & No. & $\begin{array}{c}\% \text { of } \\
\text { complications } \\
(n=12)\end{array}$ & \begin{tabular}{|c|}
$\%$ of \\
patients \\
$(n=78)$
\end{tabular} & No. & $\begin{array}{c}\% \text { of } \\
\text { complications } \\
(n=55)\end{array}$ & $\begin{array}{c}\% \text { of } \\
\text { patients } \\
(n=132)\end{array}$ \\
\hline \multicolumn{7}{|l|}{ Intraoperative } \\
\hline $\begin{array}{l}\text { Capsular } \\
\text { rupture }\end{array}$ & 1 & 8.3 & 1.3 & - & - & - \\
\hline Hyperemia & 2 & 16.7 & 2.6 & - & - & - \\
\hline $\begin{array}{l}\text { Intraopera- } \\
\text { tive subtotal }\end{array}$ & 3 & 25.0 & 3.8 & - & - & - \\
\hline \multicolumn{7}{|l|}{ Postoperative } \\
\hline $\begin{array}{l}\text { Corneal } \\
\text { edema }\end{array}$ & 4 & 33.3 & 5.1 & - & - & - \\
\hline Hyperemia & 1 & 8.3 & 1.3 & - & - & - \\
\hline $\begin{array}{l}\text { Capsular } \\
\text { opacity }\end{array}$ & 4 & 33.3 & 5.1 & - & - & - \\
\hline Recurrence & - & - & - & 41 & 74.5 & 31.1 \\
\hline $\begin{array}{l}\text { Suture } \\
\text { dehiscence }\end{array}$ & - & - & - & 9 & 16.4 & 6.8 \\
\hline Conjunctivitis & - & - & - & 5 & 9.1 & 3.8 \\
\hline $\begin{array}{l}\text { Postopera- } \\
\text { tive subtotal }\end{array}$ & 9 & 75.0 & 11.5 & 55 & 100.0 & 41.7 \\
\hline Total & 12 & 100.0 & 15.4 & 55 & 100.0 & 41.7 \\
\hline
\end{tabular}

The Blumenthal technique was used for cataract surgery[15] and excision and conjunctival autograft for pterygium.[16]

\section{RESULTS}

Misión Barrio Adentro was patients' main source of information about the availability and possibility of free surgical treatment $(58.6 \%)$. Other sources were patients who had already had surgery $(21.4 \%)$, television $(11.0 \%)$, and radio (9.0\%). Patients' age distribution was: $\geq 60$ years, $46.1 \%$ (97); 40-59 years, $42.8 \%$ (90); $18-39$ years, $10.9 \%$ (23). Some $60 \%(126)$ were men. Illiterate patients were the largest group $(49.0 \%, 103)$, followed by people with primary $(31.9 \%, 67)$, university $(10.5 \%, 22)$, and high school levels completed $(8.6 \%, 18)$. With respect to occupation, retirees accounted for the highest number $(38.6 \%, 81)$, followed by employed $(27.1 \%, 57)$, unemployed $(13.8 \%, 29)$, housewives $(11.4 \%, 24)$ and students $(9.0 \%, 19)$. Financial situation corresponded to level three income in $40.0 \%$ (84) of patient households, level two in $34.8 \%$ (73) and level one in $25.2 \%$ (53).

Among the group that received surgery, 31.9\% (67) experienced complications-15.4\% of those receiving cataract surgery $(12 / 78)$ and $41.7 \%$ of those receiving pterygium surgery (55/132). The most frequent complications of both surgeries occurred within the first three postoperative months $(75.0 \%$ in cataract patients and $100 \%$ in pterygium patients) (Table 1).

Of the 67 patients who experienced complications, 3 (4.5\%) were able to rest as instructed, at least in terms of the recommended time; $54(80.6 \%)$ had to return to work in less than two weeks, and the other $10(14.9 \%)$, in one month. In many cases, especially among women, even when they did not have to work outside the home, they had to engage in a number of activities requiring physical exertion and exposure to irritants, among negative factors. Concerning financial situation among patients with complications: $51.8 \%$ came from level three households (the worst economically), $37.6 \%$ from level two and $10.5 \%$ from level one. Complication distribution across these three household income levels for cataract surgery patients was $58.3 \%, 33.3 \%$ and $8.3 \%$, respectively; for pterygium surgery patients, $50.9 \%, 38.1 \%$ and $10.9 \%$, respectively.

Among those who had undergone surgery for cataracts-a condition more visually disabling than pterygium-55.2\% (43/78) achieved optimal postoperative VA, and only $6.4 \%$ showed VA $\leq 0.5$ three months post-surgically. In four of these cases $(5.1 \%)$, this was due to posterior capsule opacity, the most common complication of this type of surgery, a temporary condition that is correctable six months after surgery with Nd-YAF laser capsulotomy. [17] Among those who received pterygium surgery, despite some recidivism, 90.9\% (110/132) attained optimal VA (Table 2).

Table 2: Visual acuity preoperatively and three months after cataract and pterygium surgery, Táchira, Venezuela, 2008

\begin{tabular}{|c|c|c|c|c|}
\hline \multirow[b]{2}{*}{$\begin{array}{l}\text { Visual } \\
\text { acuity }\end{array}$} & \multicolumn{2}{|c|}{ Cataract $(n=78)$} & \multicolumn{2}{|c|}{ Pterygium $(n=132)$} \\
\hline & $\begin{array}{c}\text { Preoperative } \\
\text { n (\%) }\end{array}$ & $\begin{array}{c}\text { Postoperative } \\
\text { n (\%) }\end{array}$ & $\begin{array}{c}\text { Preoperative } \\
\text { n (\%) }\end{array}$ & $\begin{array}{c}\text { Postoperative } \\
\text { n (\%) }\end{array}$ \\
\hline$\leq 0.5$ & $76(97.4)$ & $5(6.4)$ & - & \\
\hline 0.6 & $2(2.5)$ & $9(11.5)$ & $5(3.7)$ & $3(2.3)$ \\
\hline 0.7 & - & $21(26.9)$ & $9(6.8)$ & $9(6.8)$ \\
\hline 0.8 & - & $23(29.5)$ & $52(39.3)$ & $11(8.3)$ \\
\hline 0.9 & - & $8(10.3)$ & $47(35.6)$ & $17(12.9)$ \\
\hline 1.0 & - & $12(15.4)$ & 19 (14.3) & 92 (69.7) \\
\hline Total & 78 (100.0) & 78 (100.0) & $132(100.0)$ & $132(100.0)$ \\
\hline
\end{tabular}

To summarize the series, demographic distribution was as expected for the context and type of health intervention. Patient records from Misión Barrio Adentro were the main source of information, complemented by examination of patient candidates. The frequency of surgical complications was high.

\section{LESSONS LEARNED}

Age and sex of these surgical patients coincide with that reported in the literature, senile cataract being the most common clinical form. $[18,19]$ In the case of pterygium, lack of access to services 
because of patients' limited income may have resulted in this surgery being performed in older-aged adults, when the condition is already advanced.

Educational level and employment status in this population are typical of Venezuela at the time and similar to other contexts in Latin America, Africa and Asia, where many poor people are illiterate or have little schooling, and, hence, few opportunities for employment. These contexts are historically characterized by less than universal health care and by levels of poverty and social inequality that also limit this population's ability to obtain medical care.

Active case-finding to identify patients in need of surgery is key for this type of health intervention in traditionally disadvantaged communities; hence, the importance of using every means at hand to disseminate a clear, simple message to the public, ensuring above all that it gets to hardest-to-reach population sectors and locales. This was possible through use of local volunteers and the media, and helped guarantee patient use of Misión Milagro services. Although quality of life as such was not measured, presumably this benefited substantially from sight improvement or restoration. González has demonstrated an improvement in vision-related quality of life after cataract surgery.[20]

As to the success of the surgery, outcomes were adversely impacted by the fact that most patients $(94.2 \%$; 198/210) who had undergone surgery had to return to their jobs prematurely after surgery for financial reasons. Moreover, much of their work required physical exertion and exposure to sun and heatgenerally inadvisable for these patients-compounded by lack of postoperative rest. All of this made patients vulnerable to the types of complications reported most frequently in the literature. [21-26] Nevertheless, sight recovery in these surgical patients was substantial, with $93.6 \%$ of cataract patients achieving at least good visual acuity.

Thus the intervention can be considered successful and potentially replicable in similar contexts, although it would be useful to design or improve preoperative patient education programs to provide more information on the importance of rest, hygiene and adequate postoperative self-management, to ascertain whether such an initiative might help overcome the negative effects of poverty and related social determinants on outcomes for low-income patients.

Our experiences indicate that humanitarian missions, bilateral accords or intergovernmental cooperation programs such as Misión Milagro can contribute to the sought-after goal of health equity, even in situations of marked social inequality where the gap often appears to be unbridgeable.

Our results also underline the importance of social determinants of health in surgical patients' ability to properly complete their postoperative recovery and maximize sight recovery. $-1 /$ -

\section{REFERENCES}

1. Pascolini D, Mariotti SP. Global estimates of visual impairment: 2010 [Internet]. Br J Ophthalmol. 2012 May [cited 2012 May 14];96(5):6148. Available from: http://bjo.bmj.com/co ntent/96/5/614.long

2. Vision 2020 The Right to Sight. Geneva: World Health Organization; 2001. p. 3.

3. Asamblea Mundial de la SaludWHA. Punto $14.17 \mathrm{del}$ orden del día 28 de mayo de 2003: Eliminación de la ceguera evitable [Internet]. World Health Organization; 2003 [cited 2012 Jan 14]. Available from: http:// whqlibdoc.who.int/wha/2003/WHA56_26_spa pdf. Spanish.

4. Estrategias para la Prevención de la Ceguera en los Programas Nacionales. Un enfoque desde el punto de vista de la atención primaria de salud. 2nd ed. Geneva: World Health Organization; 1997. p. 71-7. Spanish.

5. Monografías.com [Internet]. [place unknown]; Monografia.com S.A; 2005. Ruiz MN. El laser; [cited 2010 Mar 14]; [about 2 screens]. Available from: http://www.monografias.com/trabajos/ laser/laser.shtml. Spanish.

6. Programa VISION 2020 [Internet]. Agencia Internacional para la Prevención de la Ceguera [updated 2010 Nov 30; cited 2010 Dec 16]. Available from: http://www.VISION2020.org. Spanish.

7. Castro A, Gusmão RdA, Martínez ME, Vivas $S$, editors. Barrio Adentro: Derecho a la salud e inclusión social en Venezuela. Caracas: Pan American Health Organization; 2006. Spanish.

8. Álvarez Sintes R, Barcos Pina I. Una interpretación de la Misión Barrio Adentro desde la perspectiva de un trabajador de la salud. Caracas: Ministry of Health and Social Development (VE); 2004. 120 p. Spanish.

9. Hernández Silva JR, Padilla González CM, Ramos López M, Ríos Caso R, Río Torres M. Resultados del Programa Nacional de Prevención de Ceguera por Catarata. Cuba.
2000-2003. Rev Cubana Oftalmol. 2004 JulDec;17(2). Spanish.

10. Misión Milagro: convenio solidario [Internet]. Caracas: Ministry of Communication and Information (VE); 2005 [cited 2008 Jun 28]. Available from: www.minci.gob.ve. Spanish.

11. Gopegui B. Literatura y Misión Milagro [Internet]. Rebelión. 2006 Mar 30 [cited 2010 Jan 14]; [about 3 pages]. Available from: http://www.rebe lion.org/noticias/2006/3/29147.pdf. Spanish.

12. Rio Torres M. South-south partnerships: Cuba's vision restoration program [Internet]. Proceedings of the Unite for Sight Conference; 2009 Apr 18-19; New Haven (US). Available from: http://www.medicc.org/resources/docu ments/Unite-for-Sight-Marcelino-Rio-Presenta tion-2009.pdf

13. Villar Valdés RJ, Macías Llanes ME. Salud visual y sociedad: basamento para los cambios en la formación del especialista en Oftalmología. Rev Hum Med. 2007;7(1). Spanish.

14. Villar Valdés RJ. Oftalmología comunitaria. Ponencia de la V Jornada de Profesores Consultantes de Ciencias Médicas; 2005 Dec 15-17; Havana. Spanish.

15. Blumenthal M, Ashkenazi I, Assia E, Cahane M. Small incision manual extracapsular cataract extraction using selective hydrodissection. Ophthalmic Surg. 1992 Oct;23(10):699-701.

16. Luanratanakom P, Ratanapakom T, SuwanAoichon O, Chuck RS. Randomised controlled study of conjunctival autograft versus amniotic membrane graft in pterygium excision. $\mathrm{Br} \mathrm{J}$ Ophthalmol. 2006 Dec;90(12):1476-80.

17. Alió JL, Mulet ME, Shalaby AM, Attia WH. Phacoemulsification in the anterior chamber. J Cataract Refract Surg. 2002 Jan [cited 2012 May 14];28(1):67-75. Available from: http://www.jcrsjournal.org/article/S0886 $-3350 \% 2801 \% 2901018-5 / a b s t r a c t$
18. Llerena Díaz AY, Pérez Rodríguez AE. Principales afecciones oftalmológicas en el municipio de Guane, Pinar del Río. Rev Cubana Oftalmol. 2010 Jan-Jun;23(1):122-35. Spanish.

19. Jacomino Hernández LE, Triana Casado I, Medina Perdomo JC. Comportamiento clínico-epidemiológico de operados de catarata. Rev Medisur. 2010;8(6):1-6. Spanish.

20. González Iglesias Y, Zamora Galindo I, Fojaco Colina Y, Suárez Rodríguez B, García Álvarez H. Comportamiento de la calidad de vida relativa a salud antes y después de la cirugía de catarata. Rev Cubana Oftalmol. 2007;20(1). Spanish.

21. Hernández Silva JR, Curbelo Cunil L, Padilla González CM, Ramos López M, Río Torres M. Resultado de la cirugía de catarata por microincisiones. Rev Cubana Oftalmol. 2005 JanJun;18(1). Spanish.

22. Boyd BF. El arte y la ciencia en la cirugía de catarata. Panama City: Highlights of Ophthalmology International; 2001.412 p. Spanish.

23. Alió JL, Rodríguez Prats JL, Galal A. MICS (micro-incision cataract surgery). Panama City: Highlights of Ophthalmology International; 2004.

24. Rubinfeld RS, Pfister RR, Stein RM, Foster CS, Martin NF, Stoleru S, et al. Serious complications of topical mitomycin-C after pterygium surgery. Ophthalmology. 1992 Nov;99(11):1647-54

25. Sharma A, Gupta A, Ram J, Gupta A. Low-dose intraoperative mitomycin-C versus conjunctival autograft in primary pterygium surgery: Long term followup. Ophthalmic Surg Lasers. 2000 Jul-Aug;31(4):301-7.

26. Montero Díaz E, Capote Cabrera A, Pérez Candelaria E, Santiesteban García I, Pedroso Llanes A, Rodríguez Suárez B. Resultados del implante múltiple de lentes intraoculares en la cirugía de catarata en el Instituto Cubano de Oftalmología Ramón Pando Ferrer. Rev Cubana Oftalmol. 2010;23(1). Spanish. 


\section{THE AUTHORS}

Idalia Triana Casado, (corresponding author: idalia.triana@infomed.sld.cu), ophthalmologist with a master's degree in public health. Associate professor of ophthalmology, Dr Salvador Allende General Teaching Hospital, Havana, Cuba.
Oaris de los Ángeles Socarrás Lovio, physician with dual specialties in family medicine and ophthalmology, Manuel Díaz González Polyclinic, Artemisa, Cuba.

Nelsis Rondón Paz, ophthalmologist. Assistant professor in ophthalmology, Celia Sánchez
Manduley General Teaching Hospital, Manzanillo, Granma, Cuba.

Submitted: September 27, 2011

Approved for publication: June 27, 2012

Disclosures: None

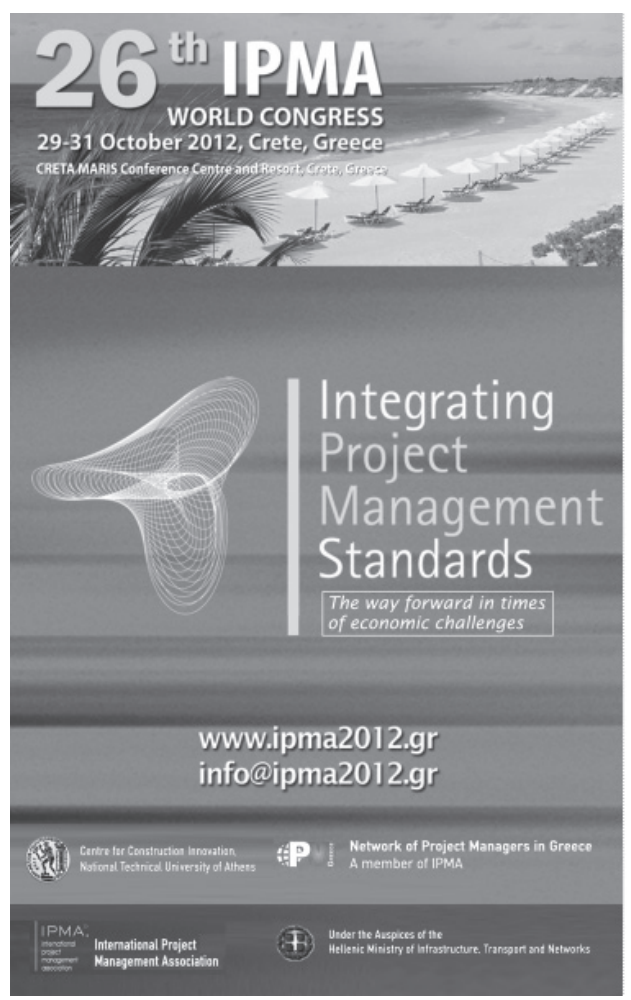

\section{SPONSORSHIP \& EXHIBITION OPPORTUNITIES}

The 26* IPMA World Congress will take place from 29-31 0ctober 2012 at the Creta Maris Conference Centre and Resort, on the beautiful island of Crete, Greece. The topic of the Congress is highly pertinent: Integrating Project Management Standards The way forward in times of economic challenges.

This "must attend" Congress offers the opportunity to present your organizations, cultivate established relationships, identify new business contacts, increase your brand awareness, demonstrate how you can bring value to your customers and meet personally and network with key marke representatives and decision makers.

For further information please refer to www.ipma2012.gr or contact the Congress Secretariatat sponsorships@ipma2012.gr or at +302103215600.

IPMA \& NATIONAL PROJECT EXCELLENCE AWARDS

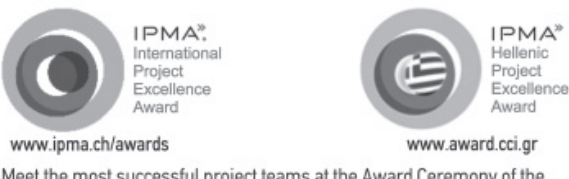

Meet the most successful project teams at the Award Ceremony of the

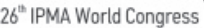

\section{GLOBAL YOUNG CREW}

C. The Global Young Crew Workshop (GYCW) is your roung crew opportunity to get to know young and project-oriented people around the world! During the workshop you will be able to participate in interactive sessions and presentations from professionallevel keynote speakers. You will have the opportunity to expand your horizons and bring new and creative views to the way you manage your projects!

$$
\text { www.ipma2012.gr }
$$

\begin{tabular}{|c|c|c|}
\hline \multicolumn{3}{|l|}{$\begin{array}{l}\text { Registration Fees } \\
\text { Delegates }\end{array}$} \\
\hline IPMA member & $\begin{array}{l}\square € 750 \\
\square € 900 \\
\square € 1100 \\
\square € 1200\end{array}$ & $\begin{array}{l}\text { Early bird (until the } 30 \text { July, 2012] } \\
\text { After } 31 \text { July up to } 30 \text { August, } 2012 \\
\text { After } 31 \text { August and before } \\
8 \text { of October. } 2012 \\
\text { After the } 8 \text { of October and On-site }\end{array}$ \\
\hline Not yet IPMA members & $\begin{array}{l}\square € 850 \\
\square € 1000 \\
\square € 1200 \\
\square € 1500\end{array}$ & $\begin{array}{l}\text { Early bird (until the } 30 \text { July, 2012) } \\
\text { After } 31 \text { July up to } 30 \text { August, 2012 } \\
\text { After } 31 \text { August and before } \\
8 \text { of October. } 2012 \\
\text { After the } 8 \text { of October and On-site }\end{array}$ \\
\hline Young Crew Global Workshop & $\begin{array}{l}\square € 450 \\
\square € 500 \\
\square € 550 \\
\square € 600\end{array}$ & $\begin{array}{l}\text { Early bird (until the } 30 \text { July, 2012) } \\
\text { After } 31 \text { July up to } 30 \text { August. } 2012 \\
\text { After } 31 \text { August and before } \\
8 \text { of October. } 2012 \\
\text { After the } 8 \text { " of October and On-site }\end{array}$ \\
\hline Full-Time Students & $\begin{array}{l}\square € 450 \\
\square € 500 \\
\square € 550 \\
\square € 600\end{array}$ & $\begin{array}{l}\text { Early bird (until the } 30 \text { July, 2012) } \\
\text { After } 31 \text { July up to } 30 \text { August, 2012 } \\
\text { After } 31 \text { August and before } \\
8 \text { of October. } 2012 \\
\text { After the } 8 \text { of October and On-site }\end{array}$ \\
\hline Regular Paper & $\begin{array}{l}\square \in 650 \\
\square \in 900 \\
\square \in 1200\end{array}$ & $\begin{array}{l}\text { Early bird (until the } 30 \text { July, 2012) } \\
\text { After } 31 \text { July up to } 30 \text { August, 2012 } \\
\text { After } 31 \text { August and before } \\
\text { 80ctober. } 2012\end{array}$ \\
\hline
\end{tabular}

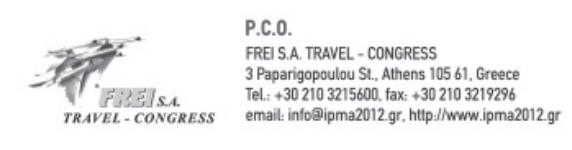

